\title{
Relationship between the drift of macroinvertebrates and the activity of brown trout in a small stream
}

\author{
F. Giroux, M. Ovidio, J.-C. Philippart and E. Baras* \\ University of Liège, Laboratory of Fish Demography and Aquaculture, 10, Chemin de la \\ Justice, B-4500 Tihange, Belgium
}

(Received 26 November 1998, Accepted 19 January 2000)

\begin{abstract}
Brown trout Salmo trutta were most active in a small stream at night, dusk and dawn when drift rate was highest, but correlations between hourly drift rates and the trout's activity varied substantially between individuals, between different dates for a single individual, and between different periods of the daily cycle. On some occasions, the trout were responsive to the total drift rate, either at night or during the day, and on others to the largest drifting organisms only (terrestrial organisms, adults of Ephemeroptera, Diptera and Trichoptera). The study supports the idea that trout adapt their activity pattern to the abundance of drifting prey, either as generalists towards any organism, or as specialists towards the largest ones.
\end{abstract}

(C) 2000 The Fisheries Society of the British Isles

Key words: foraging; drift; macroinvertebrate; stream; salmonids; Salmo trutta; telemetry.

\section{INTRODUCTION}

Bottom dwellers and benthic foragers rely on food resources whose availability varies more between different sites than between different times of the day (Ware, 1972; Baras, 1993). By contrast, most salmonids are sit-and-wait predators that forage essentially on drifting prey (Elliott, 1967, 1970, 1973; Tusa, 1968; Neveu \& Thibault, 1977; Cada et al., 1987; Angradi \& Griffith, 1990), whose abundance and diversity varies considerably between seasons, from day to day, and during the course of the day (Cada et al., 1987; Brittain \& Eikeland, 1988). Malmqvist (1988), Flecker (1992) and Douglas et al. (1992) postulated further that benthic macroinvertebrates drifted under low light intensity as a consequence of the predation pressure by visual predators, like salmonids. From spring to early autumn, salmonids usually occupy a small-sized home range (e.g. Ovidio, 1999, for brown trout Salmo trutta L. in the Aisne stream), and they may adapt to the variable availability of food resources through time budgeting. Most studies in natural environments where gut fullness of salmonids was analysed with respect to the intensity of drift, concluded that the two variables were correlated (Elliott, 1970; Allan, 1978, 1981; Bachman, 1984; Wilzbach et al., 1986; Angradi \& Griffith, 1990; Forrester et al., 1994), and that feeding occurred at the time of the highest drift density (Elliott, 1970, 1973).

However, the time scale for these analyses generally exceeded by far the periodicity of drift and trout activity, and this lack of accuracy might be of

*Author to whom correspondence should be addressed. Tel.: +32 852741 56; fax: +32 852305 92; email: E.Baras@ulg.ac.be 
importance for the understanding of fine-scale time budgeting, considering that trout can behave as generalists or as specialists (Bryan \& Larkin, 1972; Bridcut \& Giller, 1995). To date, a single, pioneer study has investigated the relationships between the drift of invertebrate prey and the foraging activity of salmonids in natural environments (cutthroat trout Oncorhynchus clarki pleuriticus Richardson; Young et al., 1997). However, it provided little insight into interindividual differences, and did not permit an analysis of individual behaviour with respect to fine-scale temporal variations in the abundance of drift in the activity centre of trout.

This study examined the diel behaviour of radio-tagged brown trout in a small stream of the Belgian Ardenne, and examined whether changes in activity level matched variations in drift abundance and composition.

\section{MATERIAL AND METHODS}

The Aisne stream is a small (40 km long; sub-basin: $184 \mathrm{~km}^{2}$; mean annual discharge: $2 \cdot 4 \mathrm{~m}^{3} \mathrm{~s}^{-1}$ ) tributary of the River Ourthe (River Meuse Basin) which flows into the River Ourthe at Bomal-sur-Ourthe. Its slope is $2 \cdot 78 \%$, and water temperature averages $9 \cdot 4^{\circ} \mathrm{C}$ $\left(0-19^{\circ} \mathrm{C}\right)$ in the study area $(0 \cdot 5-2 \cdot 0 \mathrm{~km}$ upstream of the confluence with R. Ourthe; width: $\leq 14 \mathrm{~m}$ ). The fish assemblage is typical of the trout-grayling zones (Huet, 1949), and contains brown trout, grayling Thymallus thymallus (L.), sculpin Cottus gobio (L.), stone loach Barbatula barbatula (L.) and minnow Phoxinus phoxinus (L.).

Three wild trout (A, B and C, 399, 325 and $420 \mathrm{~mm} L_{\mathrm{F}}$, and 611, 398 and $995 \mathrm{~g}$, respectively) were captured by electrofishing in spring 1996. Radio transmitters (40 MHz, coiled antenna, ATS Inc., $<2 \cdot 0 \%$ of fish body weight) were implanted surgically into the intraperitoneal cavity of anaesthetized trout, according to the methodology evaluated by Birtles (1995). Tagged trout were released at their exact place of capture, immediately after they recovered their equilibrium and showed spontaneous swimming (c. 5 min after surgery).

The activity of trout was measured during seven 24-h cycles (one trout examined per cycle; Table I) from early June to early August 1996 . Every $10 \mathrm{~min}$, fish were located to an accuracy of $c .0 .5 \mathrm{~m}$ by reference to labelled marks lining the banks of the river and triangulation using conventional methods. However, conventional tracking cannot discriminate between very small-scale changes in position and activity, especially for sit-and-wait predators. Therefore, motion-sensitive transmitters were used, tuned to transmit at $40 \pm 1$ and $80 \pm 1$ pulses $\min ^{-1}$, depending on the orientation of the fish. Each fast movement or change of direction by the fish caused the signal to shift from one pulse rate to the other. Each time the fish was positioned in the stream, transmitter pulse rates were recorded over $1 \mathrm{~min}$, and activity indices were deduced from the frequency of changes between pulse rates $\left(\Delta \mathrm{R} \min ^{-1}\right.$, Baras, 1995; Baras et al., 1998). Activity indices were expressed as a proportion of the maximum activity level, which is $53 \Delta \mathrm{R} \mathrm{min}{ }^{-1}$ for a transmitter shifting in between 40 and 80 pulses $\min ^{-1}$. This methodology was preferred to the analysis of transmitter signal strength (Clapp et al., 1990) since the signal strength of an immobile radio transmitter is not strictly constant (Baras, 1996), due to the passage of other fish and obstacles to signal propagation (e.g. leaves, branches) in the stream.

Hourly samples were collected in a standard drift net $\left(900 \mathrm{~cm}^{2}\right.$ opening; $500 \mu \mathrm{m}$ mesh; Megeco Ltd, France) that was positioned at the downstream limit of the pool-riffle sequence occupied by the trout (10-15 $\mathrm{m}$ downstream of the trout's location). As in the study by Young et al. (1997), the bottom of the net was close to the substratum, and the top extended always above the water surface. Immediately after collection, drift samples were identified to taxonomic genera, and individuals of each genus were counted. This procedure was deemed to have little effect on trout behaviour since no trout moved consecutively to drift collection. Young et al. (1997) suggested that drift biomass 


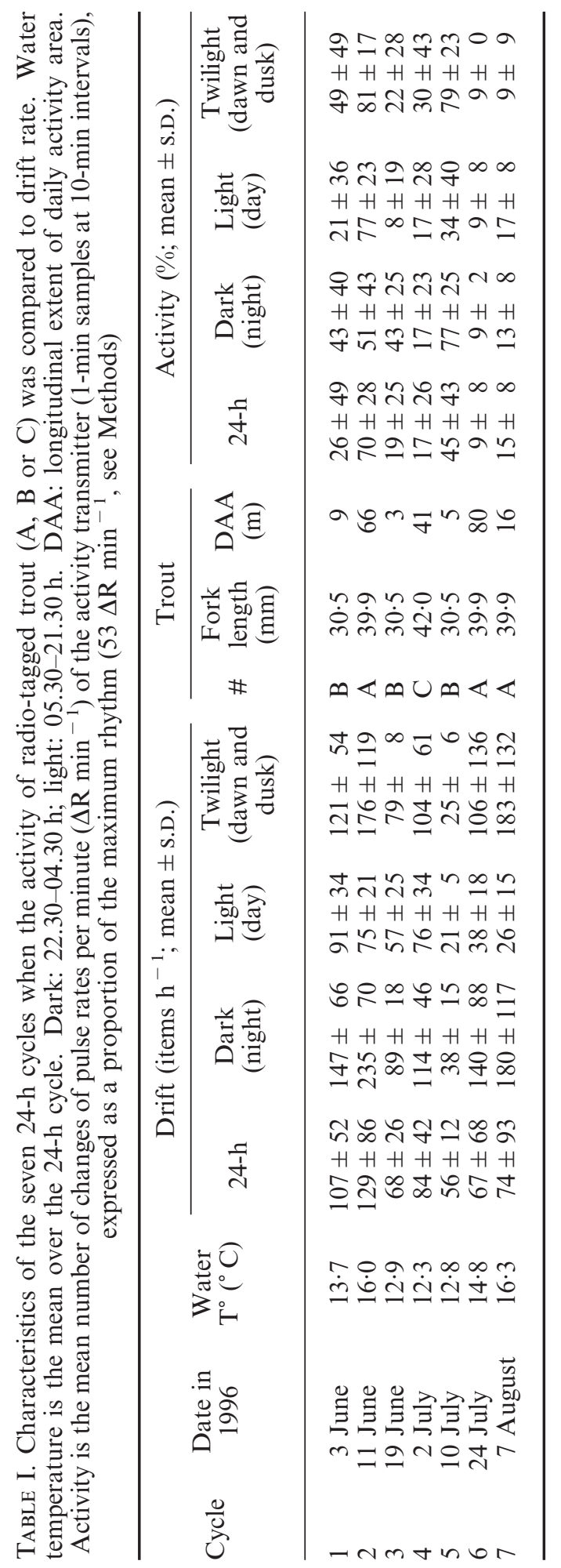


provided a better measure of nutritional value than the abundance of items, and used the former factor in their analyses. However, trout may be more sensitive or responsive to the number of drifting organisms rather than to their weight.

For this reason, the hourly activity levels of trout were compared (Spearman rank correlations) with variations in the numbers rather than biomass of drift. Because the composition of the drift was too diversified for these analyses to be conducted at the genus level, drift items were grouped in eight categories: larvae of Ephemeroptera (LE), larvae of Trichoptera (LT), larvae of Diptera (LD), adults of these three orders (AE, AT and AD, respectively), terrestrial insects (Ter) and Crustaceans (Gammarus sp., G). Distinct analyses were conducted for night-time $(<0 \cdot 1 \mathrm{~lx})$ and daytime (excluding dawn and dusk), considering that brown trout is a visual predator (Ware, 1972), and that the discrimination between different components of the drift requires minimum light intensity. Contrary to the study by Young et al. (1997), data from 24-h cycles on individual trout were treated separately in order to test for differences between individual trout, and to determine whether a single trout behaved consistently over several 24-h cycles.

\section{RESULTS}

Patterns of diel movement varied substantially between individual trout and days of study. Trout B never moved over more than $9 \mathrm{~m}$, whereas trout A occupied daily activity areas ranging from 16 to $80 \mathrm{~m}$ (Table I). Trout generally were more active during hours of darkness than during daylight, but the difference was not significant (mean \pm S.D.: $19 \cdot 3 \pm 13 \cdot 1$ v. 13.6 $\pm 12.9 \Delta \mathrm{R} \min ^{-1}$, paired $t$-test, $t=1 \cdot 11, P=0 \cdot 3078$, d.f. $=6$ ), essentially due to huge variations of activity between successive hours. A common feature of all 24-h cycles was that an individual trout could be active during the day, at night or twilight, with no clear-cut diel pattern. Mean daily activity levels were independent of the size of the daily activity area $(P=0 \cdot 8003)$, and both variables were independent of the mean drift rate over the 24 -h cycle $(P=0.8863$, and $P=0.8844$, respectively), and of water temperature $(P=0.3493$ and $P=0.6107$, respectively).

Drift rate was higher at night than during the day (mean \pm S.D.: $135 \pm 64 v$. $56 \pm 27$ items $\mathrm{h}^{-1}$; unpaired $t$-test, $t=6.09, P<0.0001$, d.f. $=166$ ), but it fluctuated considerably between $24-\mathrm{h}$ cycles (Table I). During cycle 2 in early June 1996, the hourly drift rate averaged $129 \pm 87$ items $\mathrm{h}^{-1}$ and peaked at 300 items $\mathrm{h}^{-1}$ in between 00.00 and 01.00 hours [Fig. 1(a)], whereas it averaged $26 \pm 12$ items $\mathrm{h}^{-1}$ and never exceeded 70 items $\mathrm{h}^{-1}$ during cycle 5 in early July. Larvae of Ephemeroptera were the most abundant items both at night $(45 \cdot 0 \%)$ and during the day $(35 \cdot 4 \%)$. Larvae and adults of Trichoptera, terrestrial insects and aquatic crustaceans drifted more frequently at night too. Adults of Ephemeroptera, larvae and adults of Diptera showed no clear-cut day-night periodicity, essentially due to the occurrence of episodes of high drift in the mid-morning or mid-afternoon, which alternated with periods of low drift.

Correlations between the hourly activity levels of trout and hourly drift rates varied substantially between 24 -h cycles depending on individual fish, time of the year, water temperature and drift abundance (Table II). On one occasion only (cycle 7), no single correlation was found between the abundance of drifting organisms and the activity of trout. During cycles 2, 3, 4 and 6, the activity of trout was correlated significantly with the total drift rate over the entire 24-h 


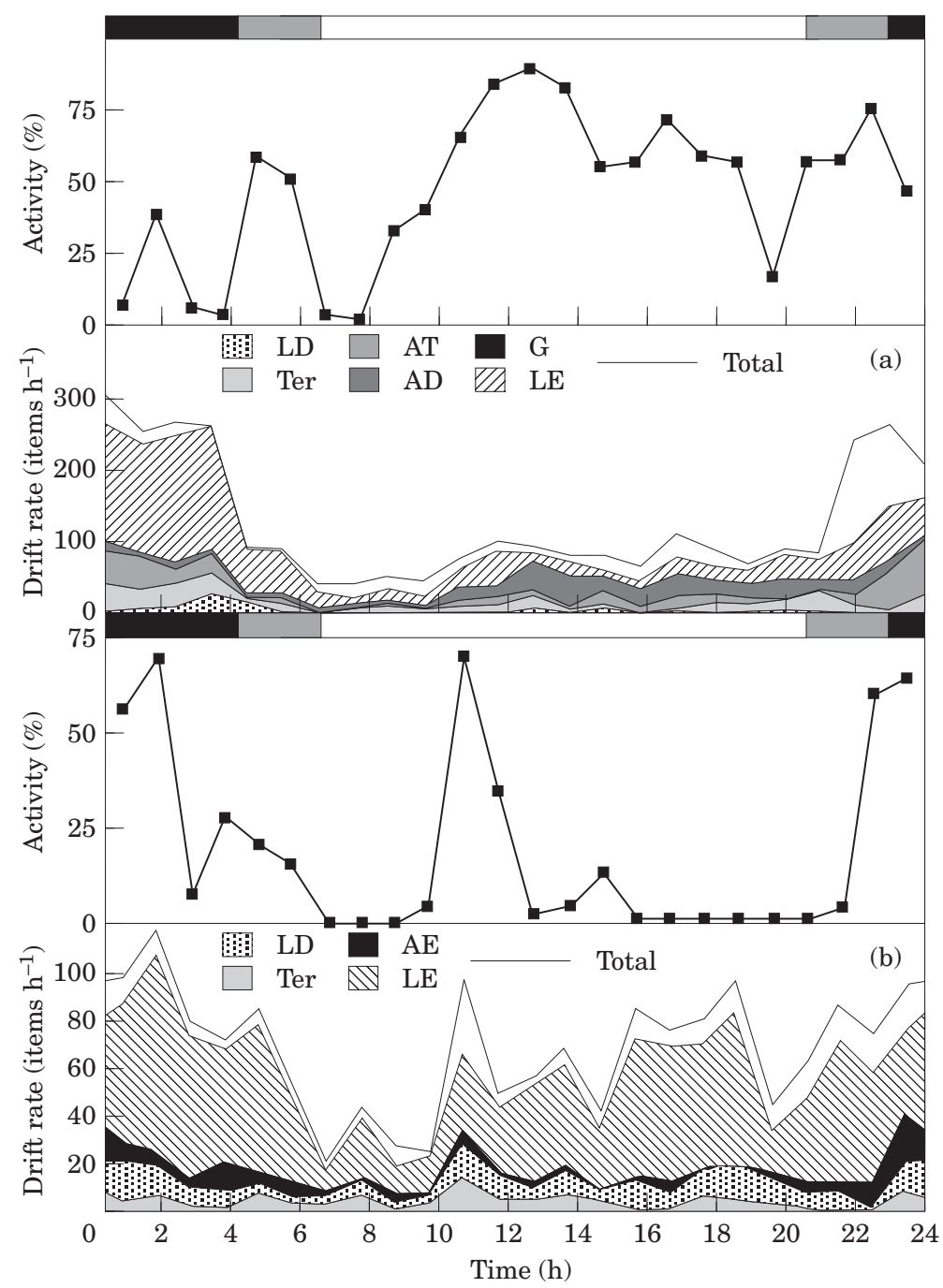

FIG. 1. Hourly variations of drift rate and activity of radio-tagged brown trout in the Aisne stream in summer 1996. Activity is the mean the number of changes of pulse rates of the motion-sensitive transmitter over six 1-min samples per hour $\left(\Delta \mathrm{R} \min ^{-1}\right)$. (a) Cycle 2, trout A; (b) cycle 3, trout B (see Table I). Correlations between drift and activity of trout are given in Table II. LE: larvae of Ephemeroptera; LT: larvae of Trichoptera; LD larvae of Diptera; AE, AT and AD are adult insects of these three orders; G: crustaceans of the genus Gammarus; Ter: adult terrestrial insects.

cycle, but more significant correlations were obtained with the largest items of the drift [adults of Diptera (2), Ephemeroptera $(3,4)$, and Trichoptera $(4,6)$, terrestrial insects (4) or larvae of Ephemeroptera and Trichoptera (6)]. During cycle 1 , the trout's activity was in phase with the total drift rate during daytime only, and in phase with drifting adults of Ephemeroptera at night. During cycle 5, trout $\mathrm{B}$ was apparently responsive to drifting adults of Trichoptera during night-time only. 
TABLE II. Relationship (Spearman rank correlations) between the hourly activity index (change of pulse rates of activity transmitters over $1 \mathrm{~min}$ intervals every $10 \mathrm{~min}$ ) of three brown trout (A, B, C) in the Aisne stream in summer 1996, and drift rate over the entire $24 \mathrm{~h}$ cycle $(\mathrm{d} . \mathrm{f} .=23)$, during the day (excluding dawn and dusk; d.f. $=15$ ) or at night (d.f. =5). Characteristics of cycles 1-7 as in Table I. G: crustaceans of the genus Gammarus; Ter: adult terrestrial insects; LE: larvae of Ephemeroptera; LT: larvae of Trichoptera; LD larvae of Diptera; AE, AT and AD are adult insects of these three orders. TD is total drift rate. - stands for no significant correlation $(P>0 \cdot 05){ }^{*} \leq 0 \cdot 05$; $* * \leq 0 \cdot 01 ; * * * \leq 0 \cdot 001$

\begin{tabular}{|c|c|c|c|c|}
\hline Cycle & Trout & $24 \mathrm{~h}$ & Night & Day \\
\hline 1 & B & - & $\mathrm{AE}(r=0.839)^{*}$ & $\mathrm{TD}(r=0 \cdot 706) * *$ \\
\hline 2 & A & $\mathrm{TD}(r=0 \cdot 421)^{*}$ & $\mathrm{AD}(r=0 \cdot 750)^{*}$ & - \\
\hline 3 & B & $\begin{array}{l}\operatorname{AE}(r=0.556)^{* *} \\
\operatorname{TD}(r=0.420)^{*}\end{array}$ & $\begin{array}{l}\mathrm{LD}(r=0.877)^{* *} \\
\operatorname{AE}(r=0.798)^{*}\end{array}$ & - \\
\hline 4 & $\mathrm{C}$ & $\begin{array}{l}\operatorname{Ter}(r=0.586) * * \\
\operatorname{TD}(r=0.539) * *\end{array}$ & $\begin{array}{l}\operatorname{Ter}(r=0.818)^{*} \\
\operatorname{AE}(r=0.807)^{*} \\
\operatorname{AT}(r=0.761)^{*} \\
\operatorname{TD}(r=0.751)^{*}\end{array}$ & $\operatorname{Ter}(r=0 \cdot 507)^{*}$ \\
\hline 5 & B & $\operatorname{AT}(r=0 \cdot 408)^{*}$ & AT $(r=0 \cdot 768)^{*}$ & - \\
\hline 6 & $\mathrm{~A}$ & $\begin{array}{l}\mathrm{LE}(r=0 \cdot 526)^{* *} \\
\operatorname{TD}(r=0 \cdot 448)^{* *}\end{array}$ & - & $\begin{array}{l}\mathrm{LE}(r=0 \cdot 816)^{* * *} \\
\operatorname{TD}(r=0.689)^{* *} \\
\operatorname{AT}(r=0 \cdot 547)^{*} \\
\operatorname{LT}(r=0.512)^{*}\end{array}$ \\
\hline 7 & A & - & - & - \\
\hline
\end{tabular}

\section{DISCUSSION}

This preliminary study supports the idea that trout generally adapt their activity pattern to the abundance of drifting prey, and substantiates the conclusions of authors who reported a correspondence between the composition of drift and the diet of salmonids (Cada et al., 1987; Hubert \& Rhodes, 1989; Angradi \& Griffith, 1990; Forrester et al., 1994; Young et al., 1997). The correlation between the activity of all brown trout and the drift rate over the seven 24-h cycles investigated here, was similar to that reported by Young et al. (1997) for cutthroat trout $(R=+0.35$ v. $R=+0.43$, respectively). However, much better correlations were obtained when examining the behaviour of individual trout (Table II), indicating that some trout were indeed time budgeting whereas others were not, or to a lesser extent. This supports the idea that trout may exhibit a wide range of behavioural tactics, and that speculations about the adaptive nature of their behavioural responses require the analysis of individual behaviour. Inter- and intra-individual differences in diel movement and activity may originate from variations of foraging efficiency or tactics in different habitat types (Ringler, 1983; Nielsen, 1992; Young et al., 1997). However both trout that were investigated over different 24-h cycles during this study used the same pool-riffle sequence consistently throughout. Decreasing drift rates throughout the summer (Table I) might have caused brown trout to turn to benthic foraging (Bachman, 1984) or to piscivory, and 
thus to exhibit activity patterns independent of drift rate (Young et al., 1997), but this remains to be determined experimentally.

Salmonids can detect prey at low light intensities (0·03-0·1 1x; Tanaka, 1970; Robinson \& Tasch, 1979; Henderson \& Northcote, 1985). Hence there was no doubt that brown trout in the present study were able to detect and capture drifting prey during the day, at dawn or dusk, when light intensity was $\geq 1 \mathrm{~lx}$. Terrestrial insects, and adults of aquatic insects such as Ephemeroptera, Diptera and Trichoptera are much bigger items than larvae. Furthermore, these large prey are found more frequently at the surface of the water, where they represent more visible targets to salmonids than prey drifting within the water column (Angradi \& Griffith, 1990; Young et al., 1997). This might account for why the activity of brown trout was correlated more frequently with the abundance of these organisms in the present study, and why these taxa are generally overabundant in the diet of salmonids during spring and summer (Wilzbach et al., 1986). This may also suggest that some trout behave as generalists towards any organism, or as specialists towards the largest ones.

In the present study, trout were always more active at dusk and dawn and during the night, than during the day. The high nocturnal activity levels observed here contrast, to some extent, with the observations that salmonids are essentially active at dusk and dawn during the summer (Ware, 1972; Elliott, 1973; Allan, 1981; Heggenes et al., 1993). Based on the correlations between hourly drift rates and fish activity, it can be put forward reasonably that brown trout were more active at night because the drift rate was higher during this period. Whether light intensity was sufficient to enable brown trout to detect, select and capture prey visually at night is uncertain. Trout may rely on senses other than vision to detect prey at low light intensity (e.g. vibrations, noise). Most probably these senses have less resolution than vision for discriminating between different prey, and cause brown trout to react to any prey, contrary to what happens during hours of light, when trout can select prey visually depending on their nature or position in the water column.

Correlations between drift rate and the activity of brown trout were generally higher at night than during the day, and this may be accounted for by several complementary hypotheses. Territoriality and agonistic interactions in salmonids are inhibited generally under low light levels (Héland, 1991). Hence the activity of trout during the night might be related more closely to foraging than during daytime, when additional social and anti-predator behaviour may mask partly the correlation between food availability and fish activity (i.e. high activity at periods of low drift). This possible confusion originates directly from the limited capacity of telemetry techniques to discriminate between different behaviours. Possibly correlations at night were better because drift rates were higher during night-time than during daytime, and exceeded some form of threshold above which trout were responsive to drift. The observation that the diurnal activity of brown trout was correlated $(P<0 \cdot 10)$ to drift rates $>70$ items $\mathrm{h}^{-1}$, whereas no significant correlation was observed for lower rates, supports this hypothesis, but experimental confirmation is required. By analogy with studies of the trout's diet, which showed the correspondence between the feeding times of trout and drift composition (Elliott, 1970, 1973), it is likely that brown trout fed predominantly during periods of high drift (i.e. at night, or occasionally 
during the day). This suggests further that the trout had presumably reached satiation before mid-day, and showed least appetite and response to prey drifting later in the day (i.e. low activity under relatively high drift). Because all factors concur with a least correlation between activity and drift during hours of light, their respective importance cannot be determined.

Before telemetry emerged as a major tool in fish behavioural ecology, the limiting factor when analysing the relationships between drift and fish activity was the frequency of gastric sampling. Nowadays, it is possible to determine the activity or position of fish with a resolution of a few seconds when using data-collecting computers connected to automatic listening (Baras et al., 1998) or positioning stations (Lagardère et al., 1996), and this exceeds by far the frequency of drift sampling with standard procedures. Coupling fine scale telemetry to fine scale drift sampling through suction pumps (Armitage, 1978; Dumont et al., 1996) might represent a substantial progress in the understanding of the trout's adaptive behaviour.

This study was supported by the Ministry of Environment (D.G.R.N.E.) within the scope of the Meuse Salmon 2000 Project. F. Giroux received an ERASMUS studentship, and M. Ovidio was a F.R.I.A. grant holder during the study. J.-C. Philippart was a research associate of the Belgian F.N.R.S.

\section{References}

Allan, J. D. (1978). Trout predation and size composition of stream drift. Limnology and Oceanography 23, 1231-1237.

Allan, J. D. (1981). Determinants of diet of brook trout (Salvelinus fontinalis) in a mountain stream. Canadian Journal of Fisheries and Aquatic Sciences 38, 184-192.

Angradi, T. R. \& Griffith, J. S. (1990). Diel feeding chronology and diet selection of rainbow trout, Oncorhynchus mykiss, in the Henry's Fork of the Snake River, Idaho. Canadian Journal of Fisheries and Aquatic Sciences 70, 355-360.

Armitage, P. D. (1978). Catches of invertebrate drift by pump and net. Hydrobiologia 60, 229-233.

Bachman, R. A. (1984). Foraging of free-ranging wild and hatchery brown trout in a stream. Transactions of the American Fisheries Society 113, 1-32.

Baras, E. (1993). A biotelemetry study of activity centres exploitation by Barbus barbus in the River Ourthe. Cahiers d'Ethologie 13, 173-174.

Baras, E. (1995). Seasonal activities of Barbus barbus (L.) -Effect of temperature on time-budgeting. Journal of Fish Biology 46, 816-828.

Baras, E. (1996). Photoperiod mediated variations of daily activity budgets in cultured tilapias Oreochromis aureus. In Underwater Biotelemetry (Baras, E. \& Philippart, J.-C., eds), pp. 187-194. Liège: University of Liège.

Baras, E., Jeandrain, D., Serouge, B. \& Philippart, J.-C. (1998). Seasonal variations of time and space utilisation by radio-tagged yellow eels Anguilla anguilla in a small stream. Hydrobiologia 371/372, 187-198.

Birtles, C. (1995). Evaluation histologique et comportementale d'une méthodologie de marquage biotélémétrique par implantation intrapéritonéale chez la truite commune juvénile (Salmo trutta L.). B.Sc. thesis, University of Liège (in French).

Bridcut, E. E. \& Giller, P. S. (1995). Diet variability and foraging strategies in brown trout (Salmo trutta): an analysis from subpopulations to individuals. Canadian Journal of Fisheries and Aquatic Sciences 52, 2543-2552.

Brittain, J. E. \& Eikeland, T. J. (1988). Invertebrate drift: a review. Hydrobiologia 166, 77-93. 
Bryan, J. E. \& Larkin, P. A. (1972). Food specialization by individual trout. Journal of the Fisheries Research Board of Canada 29, 1615-1624.

Cada, G. F., Loar, J. M. \& Cox, D. K. (1987). Food and feeding preferences of rainbow and brown trout in southern Appalachian streams. American Midland Naturalist 117, 374-385.

Clapp, D. F., Clark, R. D. \& Diana, J. S. (1990). Range, activity, and habitat of large, free-ranging brown trout in a Michigan stream. Transactions of the American Fisheries Society 119, 1022-1034.

Douglas, P. L., Forrester, G. E. \& Cooper, S. D. (1992). Effect of trout on the diel periodicity of drifting in baetid mayflies. Oecologia 98, 48-56.

Dumont, B., Suard, G., Le Coarer, Y., Carrel, G. \& Rivier, B. (1996). Towards the notion of trophic value, concepts and approaches: the brown trout example. In Ecohydraulics 2000 (Leclerc, M. et al., eds), Volume B, pp. 283-297. Québec City: INRS-Eau.

Elliott, J. M. (1967). The food of trout (Salmo trutta) in a Dartmoor stream. Journal of Applied Ecology 4, 59-71.

Elliott, J. M. (1970). Diel changes in invertebrate drift and the food of brown trout (Salmo trutta). Journal of Fish Biology 2, 161-165.

Elliott, J. M. (1973). The food of brown and rainbow trout (Salmo trutta and $S$. gairdneri) in relation to the abundance of drifting invertebrates in a mountain stream. Oecologia 12, 329-347.

Flecker, A. C. (1992). Fish predation and the evolution of invertebrate drift periodicity: evidence from neotropical streams. Ecology 73, 438-448.

Forrester, G. E., Chace, J. G. \& McCarthy, W. (1994). Diel and density-related changes in food consumption and prey selection by brook charr in a New Hampshire stream. Environmental Biology of Fishes 39, 301-311.

Heggenes, J., Krog, O. M. W., Lindas, O. R., Dokh, J. G. \& Bremner, T. (1993). Homeostatic behavioural responses in a changing environment: brown trout (Salmo trutta) become nocturnal in winter. Journal of Animal Ecology 62, 295-308.

Héland, M. (1991). Organisation sociale et territorialité chez la truite commune immature au cours de l'ontogenèse. In La Truite: Biologie et Éćologie (Baglinière, J.-L. \& Maisse, G., eds), pp. 121-149. Paris: INRA Editions.

Henderson, M. A. \& Northcote, T. G. (1985). Visual prey detection and foraging by sympatric cutthroat trout (Salmo clarki) and Dolly Varden (Salvelinus malma). Canadian Journal of Fisheries and Aquatic Sciences 42, 785-790.

Hubert, W. A. \& Rhodes, H. A. (1989). Food selection by brook trout in a subalpine stream. Hydrobiologia 178, 225-231.

Huet, M. (1949). Aperçu de la relation entre la pente et les populations piscicoles des eaux courantes. Schweizerische Zeitschrift für Hydrologie 11, 332-351 (in French).

Lagardère, J.-P., Bégout-Anras, M.-L. \& Buchet, V. (1996). The acoustic positioning system as a valuable tool for estimating the well-being of fishes in aquaculture. In Underwater Biotelemetry (Baras, E. \& Philippart, J.-C., eds), pp. 177-186. Liège: University of Liège.

Malmqvist, B. (1988). Downstream drift in Madeiran Levadas: test of hypotheses relating to the influence of predators on the drift of insects. Aquatic Insects 10, $141-152$.

Neveu, A. \& Thibault, M. (1977). Comportement alimentaire d'une population sauvage de truite fario (Salmo trutta L.) dans un ruisseau des Pyrénées atlantiques, le Lissuraga. Annales d'Hydrobiologie 8, 111-128 (in French).

Nielsen, J. L. (1992). Microhabitat-specific foraging behavior, diet, and growth of juvenile coho salmon. Transactions of the American Fisheries Society 121, $617-634$.

Ovidio, M. (1999). Annual activity cycle of adult brown trout (Salmo trutta L.): a radio-telemetry study in a small stream of the Belgian Ardenne. Bulletin Français de la Pêche et de la Pisciculture 352, 1-18. 
Ringler, N. H. (1983). Variations in foraging tactic of fishes. In Predators and Prey in Fishes (Noakes, D. L. G., Lindquist, D. G., Helfman, G. S. \& Ward, J. A., eds), pp. 159-171. The Hague: Dr W. Junk.

Robinson, F. W. \& Tasch, J. C. (1979). Feeding by Arizona trout (Salmo apache) and brown trout (Salmo trutta) at different light intensities. Environmental Biology of Fishes 4, 363-368.

Tanaka, H. (1970). On the nocturnal feeding activity of rainbow trout (Salmo gairdneri) in streams. Bulletin of the Freshwater Fisheries Laboratory (Tokyo) 20, 73-82.

Tusa, I. (1968). On the feeding biology of brown trout (Salmo trutta L.) in the Loucka Creek. Zoologica Listy 17, 379-395.

Ware, D. M. (1972). Predation by rainbow trout (Salmo gairdneri): the influence of hunger, prey density, and prey size. Journal of the Fisheries Research Board of Canada 29, 1193-1201.

Wilzbach, M. A., Cummins, K. W. \& Hall, J. D. (1986). Influence of habitat manipulations on interactions between cutthroat trout and invertebrate drift. Ecology 67, 898-911.

Young, M. K., Rader, R. B. \& Belish, T. A. (1997). Influence of macroinvertebrate drift and light on the activity and movement of Colorado River cutthroat trout. Transactions of the American Fisheries Society 126, 428-437. 